\title{
BALIKESIR MEDICAL JOURNAL
}

\section{Plasma levels of adiponectin and plasminogen activator inhibitor-1 in Turkish obese children}

\section{Obez Türk çocuklarında plazma adiponektin ve plazminojen aktivatör inhibitor-1 düzeyleri}

\section{Ferda Özbay Hoşnut ${ }^{1}$, Fatih Süheyl Ezgu ${ }^{2}$, Leyla Tümer ${ }^{2}$, Asburce Olgac ${ }^{2}$, Alev Hasanoğlu ${ }^{2}$}

1- Gazi University Hospital, Department of Pediatrics, Ankara, Turkey

2- Gazi University Hospital, Department of Pediatric Metabolism, Ankara, Turkey

\section{Öz}

Giriş: Obezitenin tek başına ateroskleroz için bir risk faktörü olduğu bilinmektedir. Obezite ve ateroskleroz ilişkisi ile ilgili bilinen başlıca faktörler dislipidemi, insülin rezistansı ve insülin duyarlılığını artırıcı bir adipositokin olan adiponektin (ADPN) eksikliğidir. Bu çalışmada, obez çocuklarda adiponektin düzeylerinin araştırılması ve adiponektin düzeyleri ile ateroskleroza yatkınlık oluşturduğu bilinen başka faktörlerin ilişkilerinin değerlendirilmesi amaçlanmıştır.

Gereçler ve yöntem: 30 obez çocuk hastanın ve 28 sağlıklı çocuğun plazma örneklerinden ADPN, plazminojen aktivatör inhbitor-1 (PAI-1), lipid profili, insülin ve tam kan örneklerinden hemoglobin A1c (HbA1c) düzeyleri belirlendi ve bu faktörlerin birbirleri ile ilișkileri araştırıldı. Obez hasta grubunda oral glukoz tolerans testi (OGTT) uygulandı ve OGTT'nin 2. saatinde ADPN ve PAI-1 düzeyleri tekrar değerlendirildi. Sonuçlar: Obez hasta grubunda, bazal ADPN ve PAI-1 düzeyleri, OGTT'nin 2. saatinde elde edilen değerlere göre daha düșük tesbit edildi. Bazal ADPN düzeyleri, vücut kitle indeksi, trigliserid düzeyleri, çok düşük dansiteli lipoprotein (VLDL) ve insulin düzeyleri ile negatif korelasyon göstermekteydi. Postprandial elde edilen ADPN ve PAI-1 bazal değerlere göre anlamlı olarak yüksek tespit edildi. Postprandial PAI-1 ve yüksek dansiteli lipoprotein (HDL) arasında ve postprandial ADPN ile insulin ve trigliserid düzeyleri arasında negatif korelasyon tesbit edildi. Trigliserid ve insulin düzeylerindeki değişiklikler ADPN'i negatif yönde etkilerken, HbA1c'deki değişiklikler pozitif yönde etkilemekteydi.

Sonuç: Çalışmamız plazma ADPN düzeylerinin atheroskleroz yatkınlığını gösteren bir belirteç olarak kullanılabileceğini ortaya koymaktadır. Anahtar Kelimeler: Çocukluk çağı obezitesi, adiponectin, plazminojen aktivatör inhibitör-1,
Gönderilme Tarihi: 19-05-2019

Kabul Tarihi:

$$
\text { 22-07-2019 }
$$

Atıf İçin: Ferda Özbay Hoşnut, Fatih Süheyl Ezgu, Leyla Tümer, Asburce Olgac, Alev Hasanoğlu,Plasma levels of adiponectin and plasminogen activator inhibitor-1 in Turkish obese childrenBalıkesir Medical Journal,2019 3(2);102-116

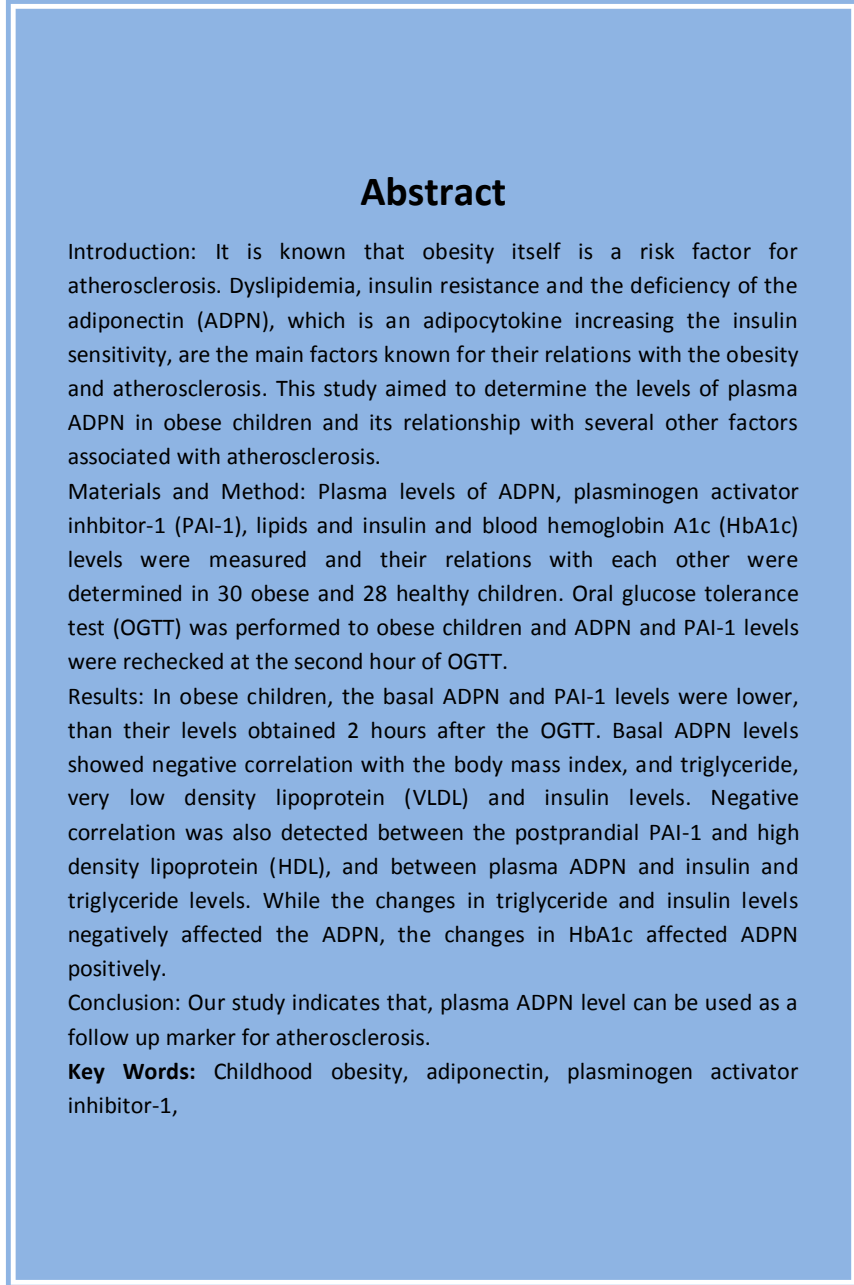

Sorumlu Yazar: Asburce Olgac

Gazi University Hospital, Department of Pediatric Metabolism,

Ankara, Turkey

E-Mail: mabolgac@yahoo.com 


\section{Introduction}

Obesity in children has been a great problem all over the world, since it is a risk factor for chronic diseases such as hypertension, hyperlipidemia, hyperinsulinemia and atherosclerosis. Thus, it is important to understand the pathophysiology and the causes of being overweight to improve prevention and therapy (1).

Nowadays, it has been known that adipose tissue is not only a passive tissue for storage of energy metabolites, but it also secretes cytokines for the body's energy equilibrium. For this reason, studies are concentrated on adiponectin (ADPN), which is an adipocytokine secreted from adipose tissue, that regulates the carbohydrate and fat metabolism, and plays a role in the development of atherosclerosis. ADPN is known to be decreased in obesity and in patients with coronary artery disease (CAD). There have been limited data on levels of ADPN in children (2).

Endothelial dysfunction and inflammation are the main factors leading to atherosclerotic cardiovascular disease and are closely related with insulin resistance (3). There has been proof that ADPN shows antiatherogenic effects via TNF-alpha, which is a proinflammatory biomarker that regulates the expression of some endothelial adhesion molecules (4). Levels of endogenous hemostatic inhibitor plasminogen activator inhibitor-1 (PAI-1), which is a cardiometabolic biomarker, increase in obese patients. The high levels of PAI-1 lead to the development of atherosclerosis by decreasing the fibrinolytic activity. The association between PAI-1 levels with insulin resistance and obesity has also been identified in children and adolescents (5).

In this study, we aimed to investigate the blood levels of ADPN and PAI-1 and their relation with atherosclerosis in obese children.

\section{Methods}

The study was carried out in Gazi University Medical School, Pediatric Metabolism and Nutrition Department. 30 obese children were included in the study. Age and sex matched 28 normal weighted, healthy children formed the control group. All the children were at prepubertal age. 
The weights of both obese and healthy children were measured by weighing scale and their heights were measured by stadiometer. Children with their body mass index (BMI) over 95\% and their relative weights over $120 \%$ were accepted as obese (6).

\section{Biochemical Analysis:}

Fasting plasma glucose, cholesterol, triglyceride, low-density lipoprotein (LDL), high-density lipoprotein (HDL), very low-density lipoprotein (VLDL), insulin, PAI-1 and ADPN and blood haemoglobin A1c (HbA1c) levels were studied in obese children and control group. In obese cases all parameters were re-evaluated after oral glucose tolerance test (OGTT).

OGTT was performed according to the guidelines of American Diabetes Association (ADA) in the obese group after 12 hours of fasting with $1.75 \mathrm{~g} / \mathrm{kg}$ (maximum $75 \mathrm{~g}$ ) oral glucose, as a suspension in $250 \mathrm{ml}$ of water. Blood glucose levels were determined just before and 120 minutes after drinking the glucose (7).

Plasma glucose, triglyceride, and HDL was measured by colorimetric-spectrophotometry with Aeroset autoanalyzer device. The VLDL level was calculated by triglyceride/ 5 , the LDL by Friedwald formula [Total Cholesterol- $(H D L+V L D L)=L D L]$. HbA1c was measured by HPLC (high performance liquid chromatograph) and plasma insulin level by automatic immunoassay methods.

For ADPN, samples were put into the EDTA tubes and were centrifuged at $3000 \mathrm{rpm}$ at $4{ }^{\circ} \mathrm{C}$ for 10 minutes and stored at $-70{ }^{\circ} \mathrm{C}$. Plasma ADPN concentration was measured by sandwich ELISA (Otsuka pharmaceutical company Ltd.), using ADPN specific antibodies (8). PAI-1 levels were also studied using ELISA method.

Informed consent was taken from the parents of all cases. The study was approved by the ethical committee of Gazi University Faculty of Medicine.

\section{Statistical Analysis}

The differences in mean parameters of independent groups were analyzed by the Mann Whitney $U$ test. The differences between basal parameters and parameters obtained at the second hour of OGTT were studied using "paired samples t-test", whereas the relations between these parametres were studied by Pearson correlation test. To obtain the normal 
range of variables, conversion of square root was administered. To search the relation between variables and ADPN and PAI-1, we used the multiple regression stepwise analysis.

\section{Results}

30 obese children (17 females, 13 males, age range: 6-9 years, mean age: 7.5 years) and 28 normal weighted heathy children (12 females, 16 males, age range: 6-9 years, mean age: 8.3 years) forming the control group were included in the study.

Table 1: The comparison of the anthropometric measurements of the cases.

\begin{tabular}{|l|l|l|l|}
\hline & $\begin{array}{l}\text { Obese } \\
(\mathbf{n}: \mathbf{3 0})\end{array}$ & $\begin{array}{l}\text { Control } \\
(\mathbf{n}: \mathbf{2 8})\end{array}$ & $\mathbf{P}$ \\
\hline Length $(\mathbf{m})$ & 1.25 & $\begin{array}{l}1.31 \\
(1.12-1.42)\end{array}$ & 0.441 \\
\hline Body mass index $\left(\mathbf{k g} / \mathbf{m}^{2}\right)$ & $\begin{array}{l}22.20 \\
(19.65-1.45)\end{array}$ & $\begin{array}{l}16.74 \\
(14.5-19.5)\end{array}$ & $<0.001$ \\
\hline Relative weight $(\%)$ & $\begin{array}{l}97.00 \\
(91-114)\end{array}$ & $<0.001$ \\
\hline Systolic blood pressure (mmHg) & $\begin{array}{l}110.00 \\
(121-153)\end{array}$ & $\begin{array}{l}100.00 \\
(80-120)\end{array}$ & 0.006 \\
\hline Diastolic blood pressure(mmHg) & $\begin{array}{l}70.00 \\
(45-85)\end{array}$ & $\begin{array}{l}65.00 \\
(60-80)\end{array}$ & $\begin{array}{l}28.25 \\
(19-38)\end{array}$ \\
\hline Body weight (kg) & $\begin{array}{l}34.75 \\
(23.5-54)\end{array}$ & $<0.001$ \\
\hline
\end{tabular}

The anthropometric data and blood pressures of the obese and control groups are shown in Table-1. Body weight, BMI, relative weights and the systolic blod pressures of obese childen were found higher than the control group $(p<0.05)$ (Table-1). Basal levels of total cholesterol, LDL and insulin of obese patients were significantly higher, whereas HDL levels were significantly lower than the control group $(p<0.05)$ (Table-2).

The basal ADPN and PAI-1 of patients and control group are shown in Table-3. ADPN levels of the obese group were found to be significantly lower than the control group, whereas, the PAI-1 levels were higher in the obese group $(p<0.05)$.

Table 2: The comparison of the basal biochemical parameters of the cases. 


\begin{tabular}{|l|c|c|c|}
\hline & $\begin{array}{c}\text { Obese } \\
(\mathbf{n}: 30)\end{array}$ & $\begin{array}{c}\text { Control } \\
(\mathbf{n}: 28)\end{array}$ & P \\
\hline Blood glucose (mg/dl) & $\begin{array}{c}86.86 \pm 7.39 \\
(87.50)\end{array}$ & $\begin{array}{c}89.42 \pm 6.94 \\
(90.00)\end{array}$ & 0.255 \\
\hline Cholesterol (mg/dl) & $\begin{array}{c}170.83 \pm 34.48 \\
(165.00)\end{array}$ & $\begin{array}{c}143.93 \pm 23.58 \\
(139.00)\end{array}$ & 0.002 \\
\hline Triglyceride (mg/dl) & $\begin{array}{c}91.5 \pm 39.08 \\
(92.50)\end{array}$ & $\begin{array}{c}82.54 \pm 57.87 \\
(69.00)\end{array}$ & 0.125 \\
\hline LDL (mg/dl) & $\begin{array}{c}105.3 \pm 25.19 \\
(105.00)\end{array}$ & $\begin{array}{c}73.21 \pm 23.72 \\
(74.00)\end{array}$ & 0.000 \\
\hline HDL (mg/dl) & $\begin{array}{c}44.87 \pm 9.03 \\
(43.50)\end{array}$ & $\begin{array}{c}53.25 \pm 11.29 \\
(50.50)\end{array}$ & 0.001 \\
\hline VLDL (mg/dl) & $\begin{array}{c}19 \pm 8.30 \\
(19.50)\end{array}$ & $\begin{array}{c}16.68 \pm 11.39 \\
(14.00)\end{array}$ & 0.110 \\
\hline Insulin (mlU/ml) & $\begin{array}{c}10.9 \pm 5.37 \\
(9.41)\end{array}$ & $\begin{array}{c}5.43 \pm 2.07 \\
(5.43)\end{array}$ & 0.000 \\
\hline HbA1c (\%) & $\begin{array}{c}4.94 \pm 1.04 \\
(4.70)\end{array}$ & $\begin{array}{c}4.89 \pm 0.52 \\
(4.80)\end{array}$ & 0.528 \\
\hline
\end{tabular}

The comparison between basal and postprandial cytokine levels (ADPN and PAI-1) is shown in Table-4. ADPN levels at the second hour of OGTT were significantly higher than basal ADPN levels ( $p=0.003)$, where PAI-1 levels were significantly lower $(p=0.001)$, (Table-4).

Table 3: Comparison of the basal values of cytokines.

\begin{tabular}{|l|l|l|l|}
\hline & $\begin{array}{l}\text { Obese } \\
(\mathrm{n}: \mathbf{3 0})\end{array}$ & $\begin{array}{l}\text { Control } \\
(\mathrm{n}: 28)\end{array}$ & P \\
\hline PAl-1 (ng/ml) & $\begin{array}{l}63.79 \pm 28.45 \\
(62.45)\end{array}$ & $\begin{array}{l}45.34 \pm 26.98 \\
(34.95)\end{array}$ & 0.006 \\
\hline Adiponectin $(\mu \mathrm{g} / \mathrm{ml})$ & $\begin{array}{l}9.1 \pm 2.60 \\
(8.53)\end{array}$ & $\begin{array}{l}10.69 \pm 3.00 \\
(10.27)\end{array}$ & 0.038 \\
\hline
\end{tabular}

The relationship between ADPN and other parameters is shown in Table 5. The correlation analysis showed changes in $\mathrm{HbA1c}$ to affect $\mathrm{ADPN}$ in a positive manner. Negative correlations between basal plasma ADPN and BMI ( $p=0.043, r=-0.37)$, triglyceride $(p=0.007$, $r=-0.479)$, VLDL $(p=0.008, r=-0.48)$ and insulin levels $(p=0.029, r=-0.399)$ were detected 
(Figure 1, 2, 3, 4). Negative correlation between plasma PAI-1 and HDL ( $p=0.012, r=-0.45)$ (Figure 5), and between plasma ADPN, insulin ( $p=0.026, r=-0.407)$ and triglyceride $(p=0.003$, $r=-0.528$ ) was found at the second hour of the OGTT (Figure 6,7$)$. Not any relationship between plasma ADPN levels and systolic and diastolic blood pressure of obese children could be detected $(p>0.05)$.

Table 4: The comparison between basal and postprandial cytokines.

\begin{tabular}{|l|c|c|c|}
\hline & Obese (basal) & Obese (postprandial) & P \\
\hline PAl-1 $(\mathrm{ng} / \mathrm{ml})$ & $63.79 \pm 28.45$ & $50.69 \pm 27.06$ & 0.001 \\
\hline Adiponectin $(\mu \mathrm{g} / \mathrm{ml})$ & $9.10 \pm 2.60$ & $9.66 \pm 2.70$ & 0.003 \\
\hline
\end{tabular}

Table 5: Correlation between ADPN and biochemical paramaters

\begin{tabular}{|l|l|l|l|}
\hline & R square & Beta & P \\
\hline $\begin{array}{l}\text { 1.Analysis } \\
\text { Constant }\end{array}$ & 0.229 & & \\
square root triglyceride & & -0.479 & 0.007 \\
\hline 2. Analysis & 0.356 & & \\
Constant & & & \\
square root triglyceride & & -0.524 & 0.002 \\
& & 0.359 & 0.029 \\
KK HbA1c & 0.495 & & \\
\hline 3. Analysis & & & \\
Constant & & -0.487 & 0.002 \\
square root triglyceride & & 0.383 & 0.011 \\
square root HbA1c & & -0.377 & 0.013 \\
\hline square root Insulin & & & \\
\hline
\end{tabular}

\section{Discussion}

It is well known that obesity in children causes metabolic and cardiovascular diseases in adult life $(2,9)$. In the recent years, relations between low ADPN level in obesity and increased risk of vascular diseases together with high PAI-1 levels and higher risk of vascular 
damage has been shown $(5,10)$. Recent studies on obesity have been focusing on cellular metabolits being released by adipose tissue (adipocytokines) including PAI-1 and ADPN (11).

Figure 1: The relation of basal plasma ADPN and BMI in the obese group.

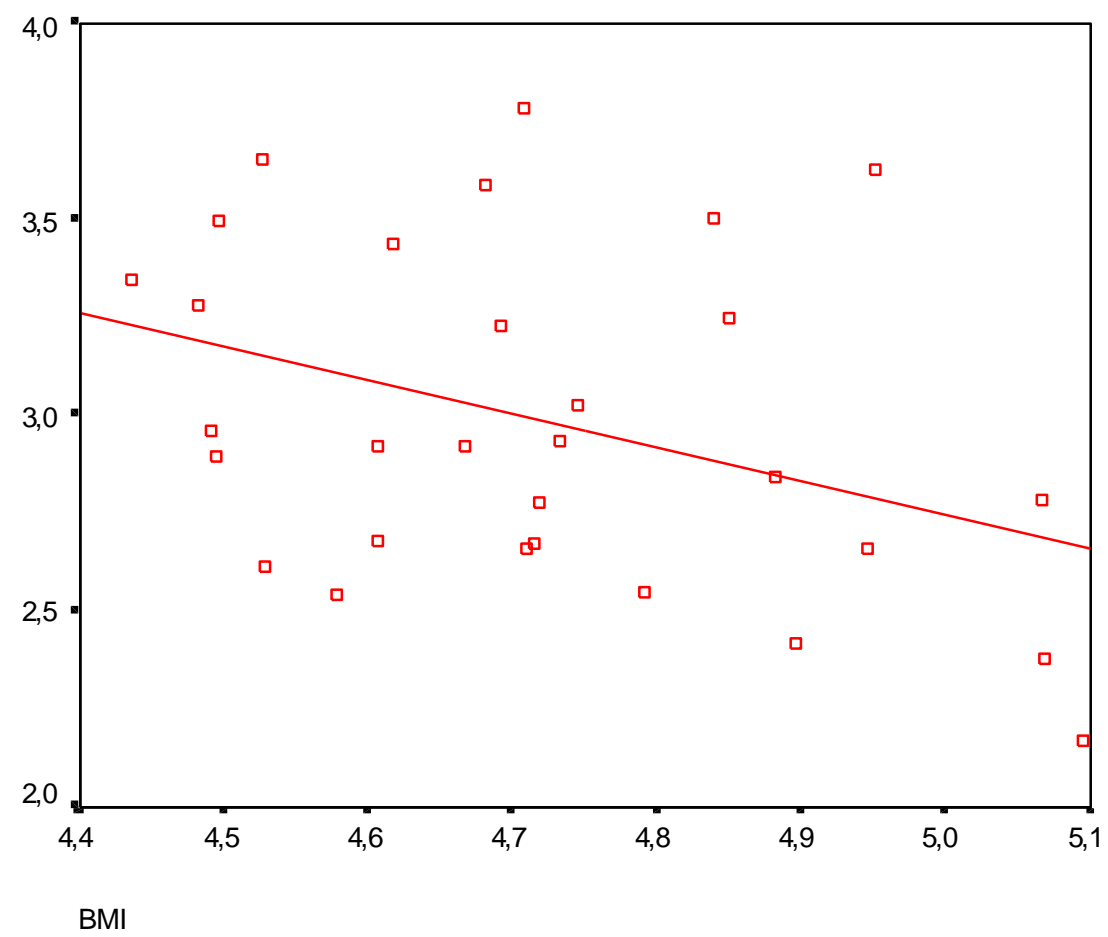

The results of low ADPN levels in obese children in our study, is in correlation with many studies in literature. Physiological concentrations of ADPN decrease the secretion of TNF alpha from macrophages and monocytes, and by affecting the expression of adhesion molecules, inhibit monocytes adhesion. Also ADPN inhibits both the expression of several growth factors on the damaged endothelial wall, and proliferation and immigration of smooth muscle cells (10). In various studies, it has been shown that the lower secretion of ADPN in obese patients, increase the risk of atherosclerosis (12).

In our study, similar to other studies reported in literature, plasma ADPN levels were measured lower in obese children when compared to healthy controls $(9.1+2.6$ (mean: 8.53) microgram $/ \mathrm{ml}$ in obese children and 10.69+3.0 (mean: 10.27) microgram $/ \mathrm{ml}$ in normal weighted children). These values are higher than the adult values reported in the literature. The higher levels of ADPN in children can be explained by lower BMI compared to adults. 
Nemet et al. (5) have also demonstrated ADPN levels to be high in obese children than normal weighted adults.

Figure 2: The relation of basal plasma ADPN and triglyceride in the obese group.

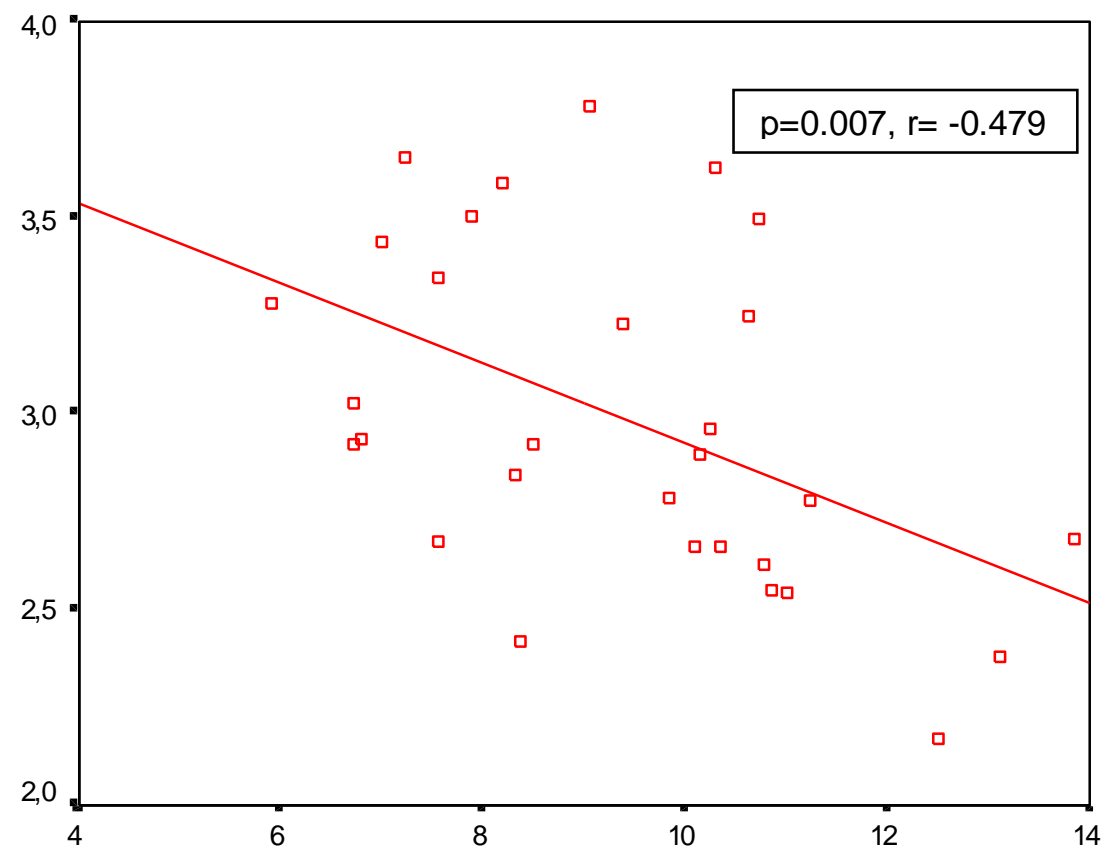

Triglycerid

Recently, the PAI-1, an essential regulator of fibrinolysis that is well known with its relation with atherosclerosis, has been showed up to be involved in various metabolic disoders including obesity. Plasma PAI-1 is derived from several sources including the vascular epithelium, adipose tissue and liver. The increase in adipose tissue derived PAI-1 is known to be due to inflammation and several proinflammatory cytokines including TNF-alpha. Decreased ADPN levels may also be contributing to increased PAI-1 production in obesity (13).

In our study, the changes of adipocytokine levels after glucose ingestion were studied and postprandial ADPN levels were found to be increased in obese children. We suggest the reason of this increase may be due to the active adipogenesis in children, and the increased response of the adipose tissue to stimulants. Hotta et al have suggested that food intake does not affect the ADPN levels directly (14). 
Figure 3: The relation of basal plasma ADPN and VLDL levels in the obese group.

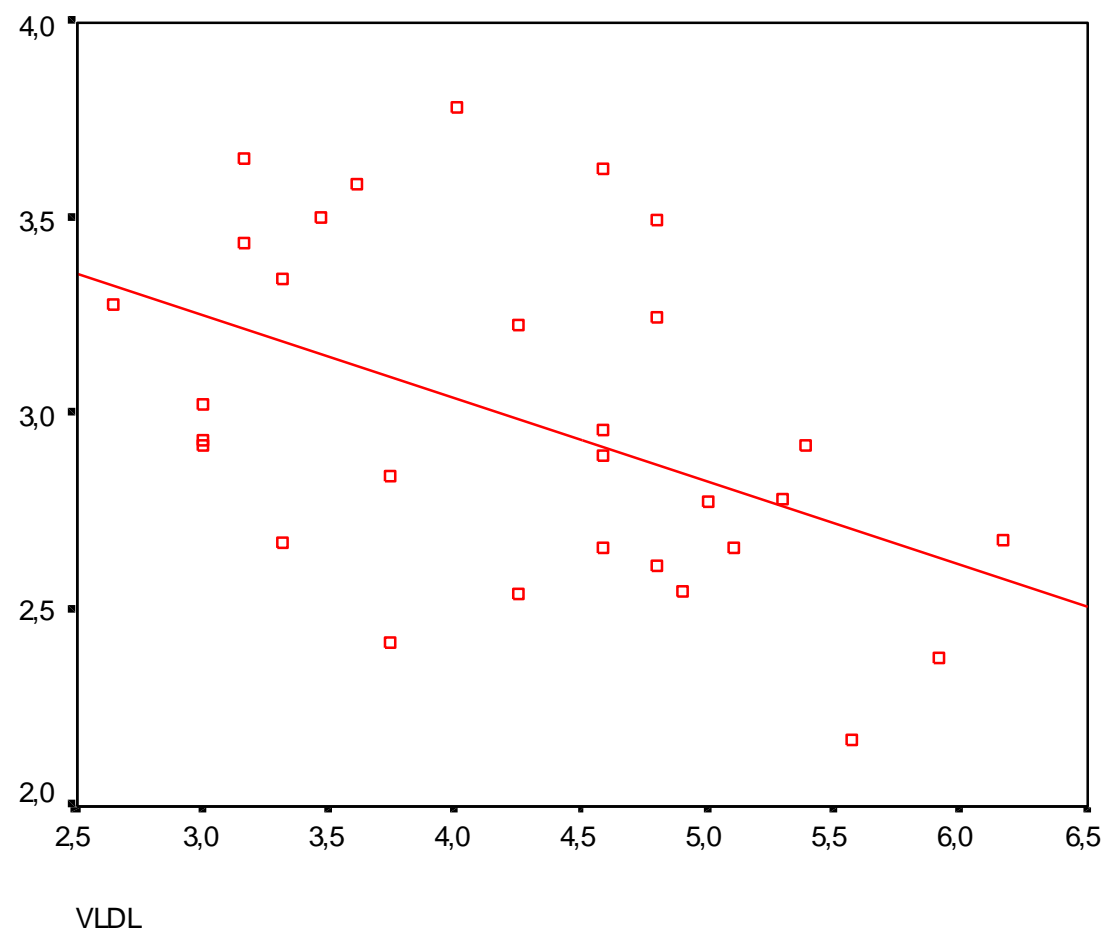

Hyperinsulinemia and insulin resistance in obese patients contribute to the development of atherosclerosis. ADPN plays a protective role on this mechanism by increasing the sensitivity of insulin through the muscle and liver tissue (15). In our study, a negative correlation between ADPN and the insulin levels at fasting and non-fasting states in obese children has been observed. Also, apart from the other variables, a positive correlation between ADPN and $\mathrm{HbA1c}$, which is an indicator of insulin resistance, has been detected. For this reason, it has been assumed that, in childhood high ADPN levels may cause insulin resistance, independent from other factors. Similar results have been shown in several studies performed in adults and children $(16,17)$.

In our study, plasma insulin level was found to be increased at non-fasting state in obese children, and this increase did not have any apparent effect on ADPN levels. Although there was a negative correlation between insulin and ADPN levels, the fact that ADPN levels did not increase at non-fasting state, may suggest that insulin may not directly affect ADPN concentrations. Fasshauer et al have compared the effects of acute versus. chronic secretion of insulin by means of in vitro expression of ADPN, and they have suggested chronic insulin therapy to cause low ADPN levels (18). Similarly, Hotta et al. (19) have shown the chronic usage of insulin to decrease ADPN levels. 
Figure 4: The relation of basal plasma ADPN and insulin in the obese group.

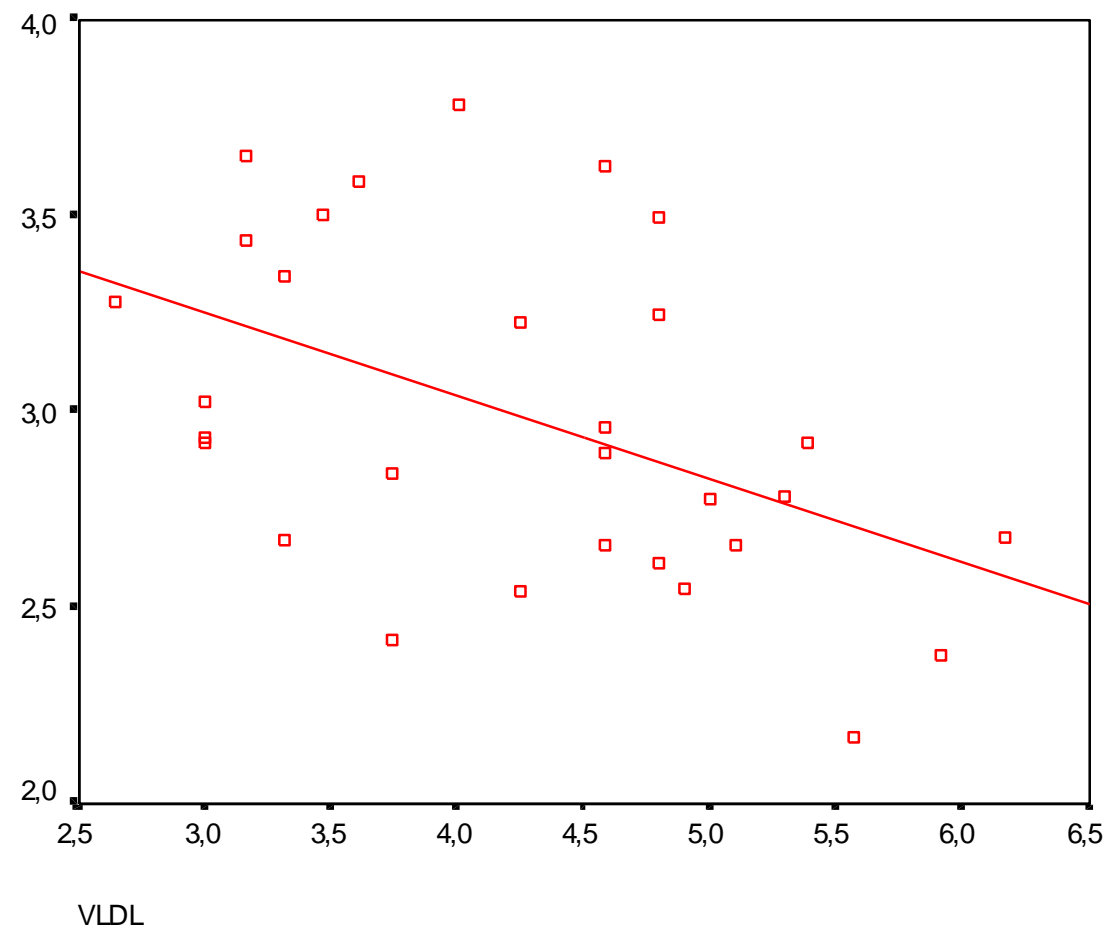

We also could not detect any relationship between plasma ADPN levels and blood pressure in obese children. This finding is in converse with several studies in the literature. Our finding may be due to lack of adequate number of patients included in the study. The ADPN concentrations have been found higher in hypertensive young males (17). Mallamaci et al. (20) also found the ADPN levels to be high in hypertensive males, independent of BMI. Recently, Ding et al have evaluated adipokines of metabolically healthy and non-healthy obese children and adolescent and found ADPN to be inversely corrrelated with systolic and diastolic blood pressure (11). ADPN inhibits lipid storage in macrophages and monocytes and prevents the development of atherosclerosis by decreasing plasma lipids and decreases the concentration of fatty acids and triglycerides by increasing the fatty acid oxidation (21). In our study, we examined the relations between lipids and plasma ADPN in obese children. There was a negative correlation between VLDL, triglyceride and plasma ADPN; and no relation was found between LDL, HDL-cholesterol and plasma ADPN levels. In a study of 180 obese patients, a negative relationship between the plasma ADPN and triglyceride levels, and positive relationship between the plasma ADPN and HDL cholesterol were shown (17). In this study, we could not find any relation between ADPN and cholesterol levels. Nemet et al. (9) has also found positive correlation of HDL cholesterol and plasma ADPN. Recently, 
Agonistis-Sobrino et al (22) have found negative correlation between ADPN and plazma TG and total cholesterol/HDL ratio in 512 Portugese adolescents. Again, the contoversial findings may be due to inadequte number of patients included in the study and inadequte measurement of the patients' blood pressures, since only one measurement was performed.

Figure 5: The relation of plasma PAI-1 and HDL at the second hour of OGTT in the obese group.

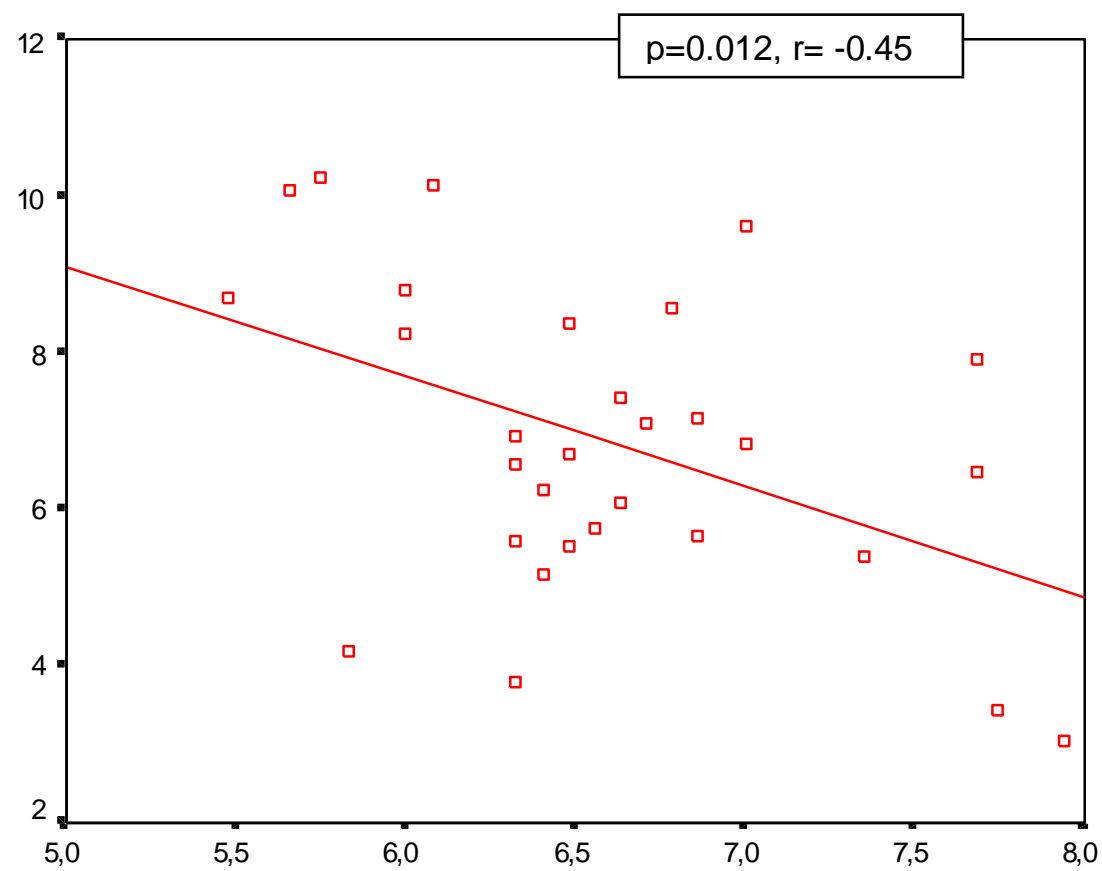

HDL

The relation between the hemostatic factors and cardiovascular diseases are demonstrated in children (23). PAI-1, an endogenous hemostatic system inhibitor, decreases the synthesis of plasmin, thus causes the formation of fibrin, activates growth factors and decomposition of matrix and finally leads to atherosclerosis (24). PAI-1 which is secreted from adipose tissue, stimulate the atherosclerotic endothelial activation in adults; are found to be higher in obesity in other studies as well $(5,23,25)$, similar to our study.

In our study we also examined the relation between PAI-1 and lipids and found out a negative correlation between HDL-cholesterol and plasma PAI-1. The positive relations with VLDL-C and PAI-1, the negative relations with HDL cholesterol have been shown in adults' studies (26). 
Figure 6: The relation of plasma ADPN and insulin at the second hour of OGTT in the obese group.

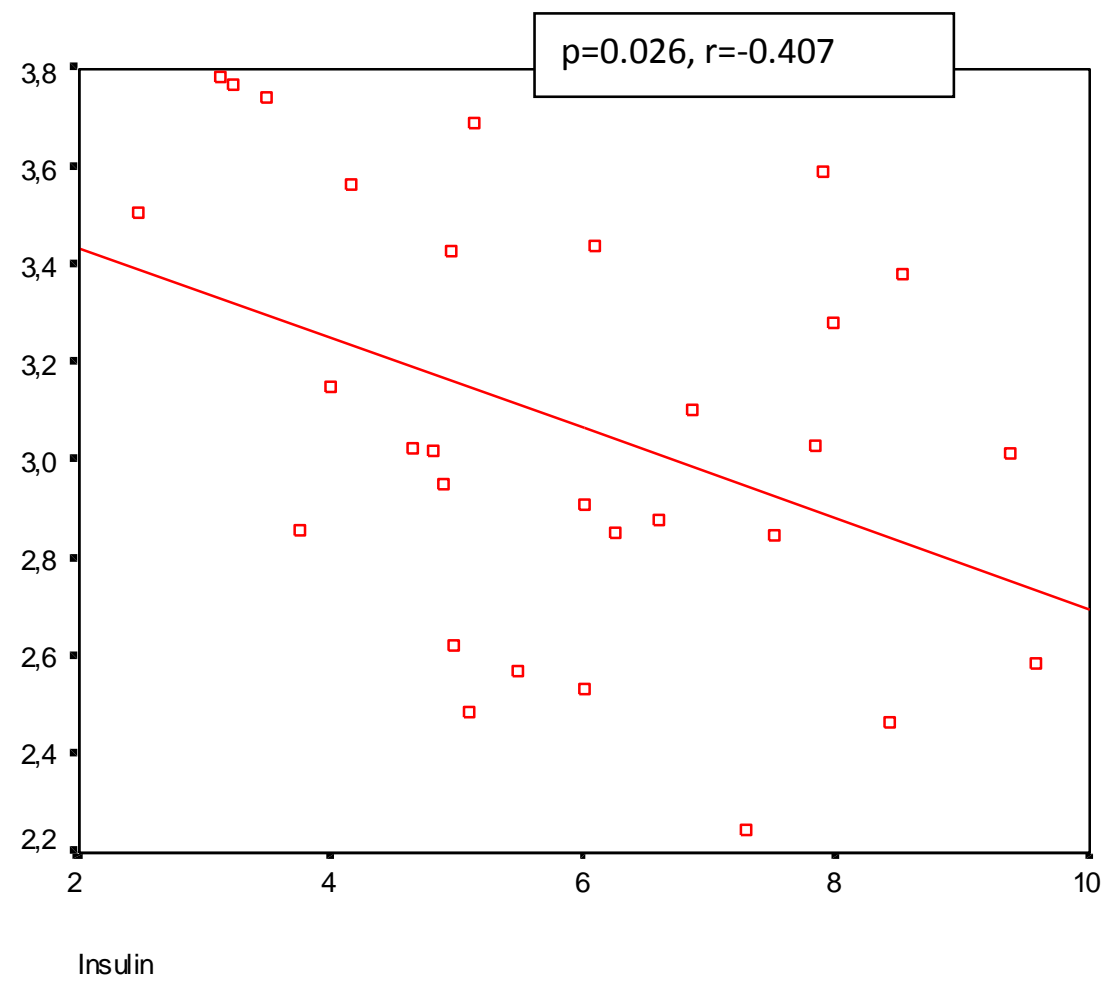

Figure 7: The relation of plasma ADPN and triglyceride at the second hour of OGTT in the obese group.

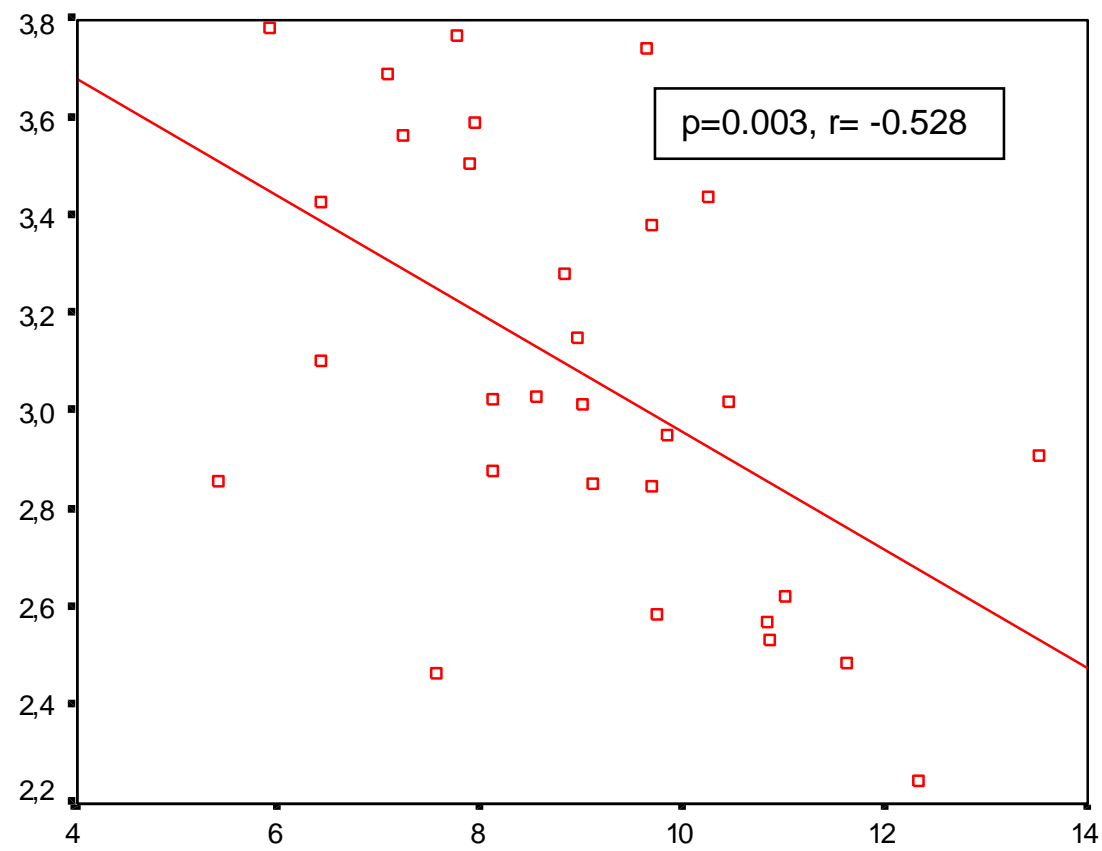

Triglyceride 
TNF-alfa increases plasma PAI-1 production of various tissues including adipocytes. Samad et al. (25) demonstrated that the inhibition of TNF-alpha by neutralizing antibodies, caused plasma PAI-1 antigen to decrease by $50 \%$, and adipose tissue PAI-1 level to decrease by 80 $85 \%$. These results verify the fact that the increase in local adipose tissue TNF-alpha has an autocrine effect on PAI-1. Increase in TNF-alpha also causes the formation of insulin resistance $(25,27)$, and decreases the expression of ADPN in adipose tissue (18). On the other hand, ADPN inhibit the activation of TNF-alpha dependant NF-kappaB through cAMP on endothelial wall (12). These results confirm the knowledge that, high TNF-alpha cause atherosclerosis and high levels of ADPN inhibit the formation of atherosclerosis.

In conclusion, since plasma ADPN is associated with atherosclerosis, ADPN levels can be used as a follow up marker for atherosclerosis in obese children. In our study, several risk factors associated with obesity were found to be high in obese children, including LDL-cholesterol, triglycerides, and PAI-1. HDL-cholesterol and ADPN, which are protective factors for the atherosclerosis, were low. More information on the pathogenesis of atherosclerosis in obesity is needed, and the recent data reveal us that the importance of prevention of obesity from early ages, to prevent everal co-morbidities, including athersclerosis.

\section{Acknowledgements:}

We would like to show our gratitude to Proffessor Tohru Funahasi, and Professor Shinji Kihara and Sachiyo Tanaka from Osaka University, Japan for their tremendous efforts for the analyses of adiponectine levels of our patients. We are immensely grateful for their contributions to our study.

\section{References:}

1) Balagopal PB, de Ferranti SD, Cook S, Daniels SR, Gidding SS, Hayman LL, et al. American Heart Association Committee on Atherosclerosis Hypertension and Obesity in Youth of the Council on Cardiovascular Disease in the Young; Council on Nutrition, Physical Activity and Metabolism; Council on Epidemiology and Prevention. Nontraditional risk factors and biomarkers for cardiovascular disease: mechanistic, research, and clinical considerations for youth: a scientific statement from the American Heart Association. Circulation. 2011 Jun 14;123(23):2749-69.

2) Fu J, Li Y, Esangbedo IC, Li G, Feng D, Li L, Xu L, et al. Circulating Osteonectin and Adipokine Profiles in Relation to Metabolically Healthy Obesity in Chinese Children: Findings From BCAMS. J Am Heart Assoc. 2018 Dec 4;7(23):e009169.

3) Sjöholm A, Nyström T. Endothelial inflammation in insulin resistance. Lancet. 2005 Feb 1218;365(9459):610-2. 
4) Okamoto $Y$, Arita $Y$, Nishida M, Muraguchi M, Ouchi N, Takahashi M, et al. An adipocytederived plasma protein, adiponectin, adheres to injured vascular walls. Horm Metab Res 2000; 32: 47-50

5) Sudi KM, Gallistl S, Weinhandl G, Muntean W, Borkenstein MH. Relationship between plasminogen activator inhibitor-1 antigen, leptin, and fat mass in obese children and adolescents. Metabolism 2000; 49: 890-895

6) Tyson N, Frank M. Childhood and adolescent obesity definitions as related to BMI, evaluation and management options. Best Pract Res Clin Obstet Gynaecol. 2018 Apr;48:158-164.

7) American Diabetes Association. 12. Children and Adolescents: Standards of Medical Care in Diabetes-2018. Diabetes Care. 2018 Jan;41(Suppl 1):S126-S136.

8) Arita $Y$, Kihara S, Ouchi N, Takahashi M, Maeda K, Miyagawa J, et al. Paradoxical decrease of an adipose-specific protein, adiponectin, in obesity. Biochem Biophys Res Commun 1999; 257: 79-83.

9) Nemet D, Wang P, Funahashi T, Matsuzawa $Y$, Tanaka S, Engelman L, et al. Adipocytokines, body composition, and fitness in children. Pediatr Res 2003; 53: 148-152.

10) Matsuda $M$, Shimomura I, Sata $M$, Arita $Y$, Nishida $M$, Maeda N, et al. Role of adiponectin in preventing vascular stenosis. The missing link of adipo-vascular axis. J Biol Chem 2002; 277 : 37487-37491.

11) Ding $W$, Cheng $H$, Chen $F$, Yan $Y$, Zhang $M$, Zhao $X$, et al. Adipokines are Associated With Hypertension in Metabolically Healthy Obese ( $\mathrm{MHO}$ ) Children and Adolescents: A Prospective Population-Based Cohort Study. J Epidemiol. 2018 Jan 5;28(1):19-26.

12) Ouchi N, Kihara S, Arita $Y$, Okamoto $Y$, Maeda K, Kuriyama H, et al. Novel modulator for endothelial adhesion molecules: adipocyte-derived plasma protein adiponectin. Circulation 1999; 100: 2473-6247

13) De Taeye B, Smith LH, Vaughan DE. Plasminogen activator inhibitor-1: a common denominator in obesity, diabetes and cardiovascular disease. Curr Opin Pharmacol. 2005 Apr;5(2):149-54.

14) Hotta $K$, Funahashi $T$, Arita $Y$, Takahashi $M$, Matsuda $M$, Okamoto $Y$, et al. Plasma concentrations of a novel, adipose-specific protein, adiponectin, in type 2 diabetic patients. Arterioscler Thromb Vasc Biol 2000; 20: 1595-1599.

15) Stefan N, Stumvoll M: Adiponectin-its role in metabolism and beyond. Horm Metab Res 2002; 34: 469-474

16) Weyer C, Funahashi T, Tanaka S, Hotta K, Matsuzawa Y, Pratley RE, et al. Hypoadiponectinemia in obesity and type 2 diabetes. close association with insulin resistance and hyperinsulinemia. J Clin Endocrinol Metab 2001; 86: 1930-19351

17) Pilacinski S, Wierusz-Wysocka B, Zozulinska-Ziolkiewicz D. Association between serum adiponectin and $\mathrm{HbA} 1 \mathrm{C}$ is independent of the severity of clinical presentation in young adults with new onset type 1 diabetes. J Endocrinol Invest. 2016; 39: 935-937.

18) Fasshauer M, Klein J, Neumann S, Eszlinger M, Paschke R. Hormonal regulation of adiponectin gene expression in 3T3-L1 adipocytes. Biochem Biophys Res Commun 2002; 290 : 1084-1089,

19) Hotta K, Funahashi T, Bodkin NL, Ortmeyer HK, Arita $Y$, Hansen $B C$, et al. Circulating concentrations of the adipocyte protein adiponectin are decreased in parallel with reduced insulin sensitivity during the progression to type 2 diabetes in rhesus monkeys. Diabetes 2001; 50: 1126-1133

20) Mallamaci F, Zoccali C, Cuzzola F, Tripepi G, Cutrupi S, Parlongo S, et al. Adiponectin in essential hypertension. J Nephrol 2002;15: 507-511

21) Ravussin E: Adiponectin enhances insulin action by decreasing ectopic fat deposition. Pharmacogenomics J 2002; 2: 4-7

22) Agostinis-Sobrinho C, Santos R, Moreira C, Abreu S, Lopes L, Oliveira-Santos J, et al. Association between serum adiponectin levels and muscular fitness in Portuguese adolescent s: LabMed Physical Activity Study. Nutr Metab Cardiovasc Dis. 2016 Jun;26(6):517-24 
23) Valle M, Gascon F, Martos R, Ruz FJ, Bermudo F, Ríos R, et al. Infantile obesity: a situation of atherothrombotic risk? Metabolism 2000; 49: 672-675

24) Juhan-Vague I, Alessi MC: Regulation of fibrinolysis in the development of atherothrombosis: role of adipose tissue. Thromb Haemost 1999; 82: 832-836

25) Samad F, Uysal KT, Wiesbrock SM, Pandey M, Hotamisligil GS, Loskutoff DJ. Tumor necrosis factor alpha is a key component in the obesity-linked elevation of plasminogen activator inhibitor 1. Proc Natl Acad Sci USA 1999; 96: 6902-6907

26) Sartori MT, Vettor R, De Pergola G, De Mitrio V, Saggiorato G, Della Mea P, et al. Role of the 4G/5G polymorphism of Pal-1 gene promoter on Pal-1 levels in obese patients: influence of fat distribution and insulin-resistance. Thromb Haemost 2001; 86: 1161-1169

27) Sakamoto T, Woodcock-Mitchell J, Marutsuka K, Mitchell JJ, Sobel BE, Fujii S. TNF-alpha and insulin, alone and synergistically, induce plasminogen activator inhibitor-1 expression in adipocytes. Am J Physiol 1999; 276: 1391-1397 